\title{
Industrial Accidents and their Prevention: A Case of Satluj Jal Viduat Nigam Limited, Shimla, Himachal Pradesh
}

\author{
Ashok Kumar Bansal*
}

Director, Gautam Institute of Management and Technology, Management, Ward No. 10, Near Bus Stand Hamirpur, Hamirpur, Himachal Pradesh 177001, India

\begin{abstract}
This paper investigated reasons of industrial accidents in Satluj Jal Viduat Naigam Limited (SJVN), Shimla, Himachal Pradesh and alternative ways to resolve them. This study collected information from purposively selected fifty (50) employees with the help of questionnaire. The study was conducted in SJVN Ltd Company which is situated in Shimla (H.P.). From the statistical findings, it may be concluded that emerges that though there are variations in rate of accidents among the respondents across demographic variables- gender, education, experience, yet these are not associated with industrial accidents as the value of chi-square was not statistically significant on statistical scale. It means there is something else beyond these factors which may account for accidents and needs to be probed. It may be suggested that the company need to work much on preventives measures, mitigating various risks and focus on satisfaction of the employees to prevent accidents.
\end{abstract}

Keywords: Industrial accident; Mitigating risk; Working conditions; Questionnaire

\section{Introduction}

Industrial accidents have been analysed and discussed for the past 100 years. A Dutch philosopher Desiderius Erasmus rightly said "Prevention is better than cure" which means it is better to stop bad things from happening, than fix them after they have already happened.

Industrial accident means a sudden and unforeseen event, attributable to any cause, which happens to a person, arising out of or in the course of his or her work, and resulting in an employment injury to that person. Accidents are preventable, but steps must be taken to prevent them. It is a legal obligation of an organization to comply with the laws, standard practises, and safety observations to avoid emergencies and accidents. There may be number of reasons behind the industrial accidents, however, human factor is one which includes unsafe acts, un- mind fitness, negligence, lack of knowledge and training. Another leading factor is working conditions. Unsafe working condition can include faulty machines, faulty designs, substandard processes, occupational hazards, fire and other hazards etc. Accidents will continue to happen if preventive measures are not to be taken. Accident prevention can be achieved by commitment and cooperation between management, safety programs, safety culture and accountability. In present era of privatization and industrialization in every field, it is essential, to coin out this issue. On this ground, the present study was proposed.

A peep into past literature in this field revealed that studies were conducted in India as well as in other countries. In the essence of work done by various scholars it may be said that majority of the researchers namely, Robertson, Kunreuther and Yaksick, Englehardt, Fleming and Bean, Evanoff, Glendon, Groover, Tompkins, Weddle, Willen, Miller, Stout-Wiegand, Handley, Larsson, reported that there is no association between demographic variables and industrial accidents [1-12]. It was also observed that a very few studies seem reported in India or in the state of Himachal Pradesh. As we know that there is lot of variation in work culture, working condition, or even in the education system etc., in the present study efforts were made to know, whether the same result will emerge in India or not. In this background, the present study was proposed to see the association between demographic variables and industrial accidents.
Hypotheses: There exist no significant relationship between demographic variables and industrial accident.

\section{Method}

The sample consisted of 50 employees working in SJVN Ltd. Company, Shimla. The base of sampling was 'convenience method of sampling' and was taken as sample size with the application of sampling. The entire study is based on primary as well as secondary data. Primary data was collected through questionnaire method. The questionnaire comprised of four demographic variables, namely: gender, experience, qualification, and marital status; and organizational variables namely; nature of the job, condition of machinery, human error, training for the prevention of accident, carelessness, stress and fatigue, unsafe acts, design of workplace, first aid, job satisfaction, working schedule and safety committee.

For finding out the results, chi-square, correlation and percentage were applied.

\section{Results}

Sample characteristics revealed that there were equal number of males and females indicating gender-wise representativeness of the sample. It also indicates no gender discrimination in the company. A little more than half of the respondents i.e. $52 \%$ were married whereas only $48 \%$ respondents unmarried. Overwhelming majority of the respondents' i.e. $90 \%$ were post graduates whereas very little i.e. $10 \%$ respondents were graduates [13]. This means all the respondents were having very good educational level and were suitable for providing good

*Corresponding author: Bansal AK, Director, Gautam Institute of Management and Technology, Management, Ward No. 10, Near Bus Stand Hamirpur, Hamirpur Himachal Pradesh 177001, India, Tel: 9418152174; 9736544172, E-mail: ashokkumarbansal2009@gmail.com

Received October 24, 2016; Accepted November 07, 2016; Published November 15,2016

Citation: Bansal AK (2016) Industrial Accidents and their Prevention: A Case of Satluj Jal Viduat Nigam Limited, Shimla, Himachal Pradesh. Intel Prop Rights. 4: 171. doi: $10.4172 / 2375-4516.1000171$

Copyright: @ 2016 Bansal AK. This is an open-access article distributed under the terms of the Creative Commons Attribution License, which permits unrestricted use, distribution, and reproduction in any medium, provided the original author and source are credited. 
information on the issue of present research. Each respondent was to indicate his/her response to the question "how do you perceive, the rate of accidents in your organization"? The answer was in three categories, viz.: high, Moderate and Low. Their responses were analysed in the context of four demographic variables: gender, experience, marital status and educational level. The association between demographic variables and rate of accidents was computed by applying Chi-square test of significance and findings are described in proceeding paragraphs.

\section{Gender and industrial accidents}

It is general perception that gender plays an important role in the world of work. Males are the dominators and females are restricted to enter into work outside home. But this conviction in present era stands pushed behind as females have entered in almost all occupational roles: technical or non-technical and proving equal partner. But now a-days we can see clearly that the males and females both are earning for the bread and butter for their life and for their family [14]. Data outlined in Table 1 below indicates that overwhelming majority (35) of respondents expressed moderate rate of accidents in SJVN. High(7) and low (8) rate of accidents found very low representation, respectively.

Similar observations were evident across gender categories: males (18) and females (17) almost equally asserted high rate of accidents in SJVN. The value of chi-square 0.671 which is less than the table value i.e. 5.991 at 0.01 level of probability indicates there is no significant association between gender and perception of rate of industrial accidents. Hence, the hypothesis 'there exist no significant relationship between gender and industrial accident' is accepted.

\section{Experience and industrial accident}

Experience is very important because it is generally perceived that a person having more experience is expected to perform his task in a very effective and efficient way, in addition to this it also improve the interpersonal relationship of the person (Table 2).

In the above table efforts has been made to analyze the association between Condition of Machinery and prevention of industrial accidents. To reveal the meaningful information chi-square test which is also known as the "Goodness of Fit" it is found that calculated value

\begin{tabular}{|c|c|c|c|}
\hline \multirow{2}{*}{ Rate of accident } & \multicolumn{2}{|c|}{ Gender } & \multirow{2}{*}{ Total } \\
\cline { 2 - 3 } & Male & Female & \\
\hline High & $4(8 \%)$ & $3(6 \%)$ & $7(14 \%)$ \\
\hline Moderate & $18(36 \%)$ & $17(34 \%)$ & $8(70 \%)$ \\
\hline Low & $3(6 \%)$ & $5(10 \%)$ & $50(100 \%)$ \\
\hline Total & $25(50 \%)$ & $25(50 \%)$ & Table value=5.991 \\
\hline $\mathfrak{x}^{2}=0.671$ & $\mathrm{df}=2$ & $\begin{array}{c}\text { Level of } \\
\text { significance=0.05 }\end{array}$ & \\
\hline
\end{tabular}

Table 1: Gender and rate of accidents.

\begin{tabular}{|c|c|c|c|c|c|}
\hline \multirow{2}{*}{ Category } & \multicolumn{4}{|c|}{ Experience } & \multirow{2}{*}{ Total } \\
\cline { 2 - 5 } & $\begin{array}{c}\text { Less than } \\
\text { 2 years }\end{array}$ & $\mathbf{2 - 3}$ years & $\begin{array}{c}\mathbf{3 - 4} \\
\text { years }\end{array}$ & $\begin{array}{c}\text { More than } \\
\text { 4 years }\end{array}$ & \\
\hline $\begin{array}{c}\text { High rate of } \\
\text { accident }\end{array}$ & $1(2 \%)$ & $1(2 \%)$ & $4(8 \%)$ & $1(2 \%)$ & $7(14 \%)$ \\
\hline $\begin{array}{c}\text { Moderate rate of } \\
\text { accident }\end{array}$ & $3(6 \%)$ & $14(28 \%)$ & $\begin{array}{c}15 \\
(30 \%)\end{array}$ & $3(6 \%)$ & $35(70 \%)$ \\
\hline $\begin{array}{c}\text { Low rate of } \\
\text { accident }\end{array}$ & 0 & $1(2 \%)$ & $4(8 \%)$ & $3(6 \%)$ & $8(16 \%)$ \\
\hline Total & $4(8 \%)$ & $16(32 \%)$ & $23(46 \%)$ & $7(14 \%)$ & $50(100 \%)$ \\
\hline$\chi^{2}=7.522$ & $\mathrm{df}=6$ & Level of significance=0.05 & $\begin{array}{c}\text { Table } \\
\text { value=12.591 }\end{array}$ \\
\hline
\end{tabular}

Table 2: Experience and Rate of Accidents. i.e. 7.522 which is less than the table value i.e. 12.591 at 0.05 significance level, hence the hypothesis 'there exist no significant relationship between experience and industrial accident' is accepted.

\section{Marital status and industrial accidents}

Marriage is that stage of the life which brings more sense of responsibility in once life. It is that stage of life through which almost all will pass. Generally it is assumed that a married person will be more responsible and mature enough. In present study efforts has been made to explore the association between marital status and industrial accidents. The detailed description of this is given as below (Table 3 ).

In the above table efforts has been made to analyze the association between human error and prevention of industrial accidents. To reveal the meaningful information chi-square test which is also known as the "Goodness of Fit" it is found that calculated value i.e. 1.149 which is less than the table value i.e. 5.991 at 0.05 significance level, hence the hypothesis 'there exist no significant relationship between marital status and industrial accident' is accepted. Thus it can be said that marital status is not the major reason of the industrial accident because whether the employee is married or not it is not much important when it comes to cause/reason of the accidents, but yes, we can't ignore the fact that married employee will have much more responsibilities and these may cause stress which may be the reason of the industrial accident.

\section{Educational qualification and industrial accidents}

Education plays a major role in one's life in many aspects. It is generally assumed that education bring lot of changes like, knowledge, thinking, behaviour, maturity, and perception etc. In the present study this factor is considered to see the association between educational qualification and industrial accidents (Table 4).

In the above table efforts has been made to analyze the association between Working Schedule and prevention of industrial accidents. To reveal the meaningful information chi-square test which is also known as the "Goodness of Fit" it is found that calculated value i.e. 3.265 which

\begin{tabular}{|c|c|c|c|}
\hline \multirow{2}{*}{ Category } & \multicolumn{2}{|c|}{ Marital status } & \multirow{2}{*}{ Total } \\
\cline { 1 - 3 } & Married & Unmarried & $7(14 \%)$ \\
\hline $\begin{array}{c}\text { High rate of } \\
\text { accident }\end{array}$ & $4(8 \%)$ & $3(6 \%)$ & $35(70 \%)$ \\
\hline $\begin{array}{c}\text { Moderate rate of } \\
\text { accident }\end{array}$ & $19(38 \%)$ & $16(32 \%)$ & $8(16 \%)$ \\
\hline $\begin{array}{c}\text { Low rate of } \\
\text { accident }\end{array}$ & $6(12 \%)$ & $2(4 \%)$ & $50(100 \%)$ \\
\hline Total & $29(58 \%)$ & $21(42 \%)$ & $\begin{array}{c}\text { Table } \\
\text { value=5.991 }\end{array}$ \\
\hline$\varkappa^{2}=1.149$ & $\mathrm{df}=2$ & $\begin{array}{c}\text { Level of } \\
\text { significance=0.05 }\end{array}$ & \\
\hline
\end{tabular}

Table 3: Marital Status and Rate of Accidents.

\begin{tabular}{|c|c|c|c|c|}
\hline \multirow{2}{*}{ Category } & \multicolumn{3}{|c|}{ Education } & \multirow{2}{*}{ Total } \\
\cline { 2 - 4 } & $\begin{array}{c}\text { Senior } \\
\text { Secondary }\end{array}$ & Graduate & $\begin{array}{c}\text { Post } \\
\text { graduate }\end{array}$ & \\
\hline $\begin{array}{c}\text { High rate of } \\
\text { accident }\end{array}$ & $1(2 \%)$ & $6(12 \%)$ & 0 & $7(14 \%)$ \\
\hline $\begin{array}{c}\text { Moderate rate } \\
\text { of accident }\end{array}$ & $6(12 \%)$ & $28(56 \%)$ & $1(2 \%)$ & $35(70 \%)$ \\
\hline $\begin{array}{c}\text { Low rate of } \\
\text { accident }\end{array}$ & $0(0 \%)$ & $7(14 \%)$ & $1(2 \%)$ & $8(16 \%)$ \\
\hline Total & $7(14 \%)$ & $41(82 \%)$ & $2(4 \%)$ & $50(100 \%)$ \\
\hline$\varkappa^{2}=1.149$ & $\mathrm{df}=4$ & Level of significance=0.05 & $\begin{array}{c}\text { Table } \\
\text { value }=9.487\end{array}$ \\
\hline
\end{tabular}

Table 4: Education and rate of accidents. 
Citation: Bansal AK (2016) Industrial Accidents and their Prevention: A Case of Satluj Jal Viduat Nigam Limited, Shimla, Himachal Pradesh. Intel Prop Rights. 4: 171. doi: 10.4172/2375-4516.1000171

Page 3 of 3

is less than the table value i.e. 9.487 at 0.05 significance level, hence the hypothesis 'there exist no significant relationship between educational qualification of employees and industrial accident' is accepted.

\section{Conclusion}

From the statistical findings, it may be concluded that emerges that though there are variations in rate of accidents among the respondents across demographic variables- gender, education, experience, yet these are not associated with industrial accidents as the value of chi-square was not statistically significant on statistical scale. It means there is something else beyond these factors which may account for accidents and needs to be probed. It may be suggested that the company need to work much on preventives measures, mitigating various risks and focus on satisfaction of the employees to prevent accidents.

\section{References}

1. Robertson LS (1983) Injuries; Causes, Control Strategies and Public Policy. Lexington Books, Massachusetts 252: 1186.

2. Yaksick KHR (1988) Risk management tools for bridging the expert/layperson gap. Industrial Crisis Quarterly 2: 271-282.

3. Englehardt HJ, Fleming L, Bean J (1999) Occupational health and safety amongst municipal solid waste workers in Florida. Waste Management \& Research 17: 369-377.
4. Evanoff B, Abedin S, Grayson D, Dale A, Wolf L, et al. (2002) Is disability underreported following work injury? Journal of Occupational Rehabilitation 12: 139-150.

5. Groover DR, Krause TR, Hindley JH (1992) Using the behaviour based safety process to increase injury reporting. Professional Safety 37: 24-27.

6. Willen J (2000) Safety incentive programs: problem solver or troublemaker? Safety and Health 162: 50-53.

7. Stout-Wiegand N (1987) Characteristics of Work-Related Injuries Involving Forklift Trucks. Journal of Safety Research 18: 179-190.

8. Handley W (1969 Industrial safety handbook. McGraw-Hill, London.

9. Larsson TJ (1990) Severe Hand Injuries among Swedish Farmers. Journal of Occupational Accidents 12: 295-306.

10. Kothari CR (2004) Research Methodology Methods \& Techniques, Second Edition, New Delhi. New Age International Publisher pp: 1-2.

11. Larsson TJ (1991) We need applied prevention - not statistics. Journal of Occupational Health \& Safety - Australia and New Zealand 7: 287-294.

12. Dwight AH (2000) Safety and is structured to implement. Public Roads 63: 4.

13. Tony Greenfield (1996) Research Methods: Guidance for Postgraduates. London: Arnold p: 3.

14. Williams EA, Priestley SE (1980) Fork Lift Truck Injuries. Journal of the Society of Occupational Medicine 30: 149-152. 